ISSN 2356-3397 (Print) | ISSN 2597-4505 (Online)

\title{
PENGARUH PELATIHAN PLIOMETRIK DAN KECEPATAN TERHADAP DAYA LEDAK OTOT TUNGKAI PEMAIN BOLA VOLI PUTRI SMP
}

\author{
Addy Putra Indrawan ${ }^{1}$, Wahjoedi ${ }^{2}$, Suratmin ${ }^{3}$ \\ ${ }^{1}$ Prodi Pendidikan Olahraga Pasca Sarjana, Universitas Pendidikan Ganesha \\ Singaraja, Indonesia \\ ${ }^{2,3}$ Prodi Pendidikan Jasmani, Kesehatan dan Rekreasi, \\ Universitas Pendidikan Ganesha \\ Singaraja, Indonesia \\ e-mail: addyputra2324@gmail.com, wahjoedi@undiksha.ac.id, \\ suratmin@undiksha.ac.id
}

\begin{abstract}
Abstrak
Penelitian ini bertujuan untuk menganalisis: 1) hasil latihan quick leap lebih baik dari double leg speed hop, 2) interaksi antara metode latihan dan kecepatan berpengaruh terhadap daya ledak otot tungkai, 3) hasil latihan quick leap lebih baik dari latihan doubele leg speed hop pada peserta yang memiliki daya ledak otot tungkai kecepatan tinggi, dan 4) hasil latihan quick leap lebih baik dari latihan double leg speed hop pada peserta yang memiliki daya ledak otot tungkai kecepatan rendah. Jenis penelitian yang digunakan adalah eksperimen dengan rancangan treatment by level dengan dua ketegori $2 \times 2$. Populasi pada penelitian ini adalah 75 orang. Sampel berjumlah 40 orang ditentukan dengan kategori daya ledak otot tungkai kecepatan tinggi dan rendah. Teknik analisis data menggunakan anava 2 jalur pada taraf signifikansi 0,05. Instrumen penelitian menggunakan vertical jump untuk mengukur tes keterampilan daya ledak otot tungkai. Hasil analisis data menunjukkan: 1) ) hasil latihan quick leap lebih baik dari latihan doubele leg speed hop dengan mean difference $35,900,2)$ terdapat interaksi antara bentuk latihan dan daya ledak otot tungkai dengan sig. $(0,00)<(0,05)$, 3) hasil latihan quick leap lebih baik dari latihan doubele leg speed hop pada peserta yang memiliki daya ledak otot lengan tinggi dengan mean difference 33,78, dan 4) Hasil latihan quick leap lebih baik dari latihan double leg speed hop pada peserta yang memiliki daya ledak otot tungkai kecepatan rendah dengan mean difference 24,44.
\end{abstract}

Kata kunci: pliometrik, daya ledak otot tungkai, kecepatan.

\begin{abstract}
This study aimed at analyzing: 1) the result of quick leap training and double leg speed hop training ; 2) the effect of interaction between training and speed on the explosive power of leg muscle; 3) the result of quick leap training and double leg speed hop in the players with high speed of the explosive power of leg muscle, and 4) the result of quick leap and double leg speed hop in the players with low speed of the explosive power of leg muscle. This study was a quasi experimental research with the $2 \times 2$ category treatment by level design. The sample consisted of 40 students determined with high and low speed of the explosive power of leg muscle categories. The study used the two-way ANOVA technique at 0.05 level of significance to analyze the data. The vertical jump was used to measure the skill of the explosive power of leg muscle. The result of data analysis showed: 1) the result of quick leap training was better than double leg speed hop with the mean difference of 35.900; 2) There was an interaction between the form of the training and the explosive power of leg muscle, $(0.00)<(0.05) 3)$ The result of quick leap training was better than that of double leg speed hop in the players with high speed of the explosive power of leg muscle with the mean difference of 33.78; and 4) the result of quick
\end{abstract}


ISSN 2356-3397 (Print) | ISSN 2597-4505 (Online)

leap training was better than that of double leg speed hop in the players with slow speed of the explosive power of leg muscle the mean difference of 24.44 .

Keywords: plyometric, explosive power of leg muscle, speed

\section{PENDAHULUAN}

Pengembangan diri merupakan salah satu program untuk membina potensi dan kreasi siswa sesuai dengan bakat dan minatnya. Kegiatan pengembangan diri dilakukan melalui kegiatan pelayanan konseling dan kegiatan ekstra kurikuler. Kegiatan pengembangan diri difasilitasi/ dilaksanakan oleh konselor, dan kegiatan ekstra kurikuler dapat diselenggarakan oleh guru dan atau Pembina olahraga sesuai dengan kemampuan dan kewenangannya. Pengembangan diri yang dilakukan dalam bentuk kegiatan kegiatan ekstrakurikuler dapat mengembangkan kompetensi dan kebiasaan dalam kehidupan sehari-hari peserta didik. Pengembangan diri bertujuan memberikan kesempatan kepada peserta didik untuk mengembangkan dan mengekspresikan diri sesuai dengan kebutuhan, potensi, bakat, minat, kondisi dan perkembangan peserta didik dengan memperhatikan kondisi sekolah/ madrasah (Sukradati et al., 2013). Pengembangan diri dilaksanakan melalui kegiatan terpogram dilaksanakan dengan perencanaan secara khusus dan terjadwal. Sedangkan kegiatan yang tidak terpogram adalah kegiatan yang dilaksanakan secara langsung oleh pendidik di sekolah yang diikuti oleh semua peserta didik. Pelaksanaan kegiatan tidak terpogram dilakukan melalui kegiatan rutin, kegiatan spontan dan kegiatan keteladanan.

Kegiatan ekstrakurikuler, terutama olahraga tentu sangat membutuhkan suatu kebugaran jasmani agar bisa melakukan aktivitas olahraga dengan baik dalam kurun waktu yang diperlukan. Olahraga merupakan suatu aktivitas fisik/jasmani untuk melakukan suatu gerakan secara sistematis sehingga tujuan bisa tercapai. Kondisi fisik yang baik harus dimiliki oleh setiap atlet atau olahragawan sesuai dengan aktivitas olahraga atau cabang olahraga yang ditekuninya. Daya ledak merupakan salah satu komponen-komponen dari kondisi fisik. Daya Ledak adalah kemampuan untuk melakukan aktivitas secara tiba-tiba dan cepat dengan mengerahkan seluruh kekuatan dalam waktu yang singkat (Nala, 2011: 9). Daya ledak menyangkut kekuatan dan kecepatan otot berkontraksi secara dinamis dan eksplosif serta mengeluarkan kekuatan otot maksimal dalam waktu yang secepat-cepatnya. Daya ledak otot tungkai adalah kemampuan otot tungkai untuk mengerahkan kekuatan maksimal dengan kontraksi yang sangat cepat atau singkat untuk dapat mengatasi beban yang didapat atau yang diberikan (Ariani, 2011). Sehingga daya ledak otot tungkai merupakan salah satu daya ledak yang dibutuhkan dalam pencapian prestasi olahraga salah satunya pada cabang olahraga bola voli.

Pemain bola voli sangat penting memiliki kondisi fisik yang baik. Melalui proses latihan fisik yang terprogram dengan baik, faktor-faktor kondisi fisik yang terlibat dalam olahraga bola voli dapat dikuasai. Pemain bola voli harus memiliki kualitas kebugaran jasmani yang prima. Ini akan berdampak positif terhadap kebugaran mental, psikis, yang akan berpengaruh langsung pada penampilan teknik bermain. Permainan bolavoli sangat membutuhkan kualitas kekuatan, daya tahan, power otot tungkai, power otot lengan, kecepatan, kelincahan, dan koordinasi gerak yang baik. Aspek tersebut sangat dibutuhkan agar dapat bergerak dan bereaksi selama pertandingan. Untuk menjadi pemain bola voli yang baik, pemain bola voli memerlukan penguasaan teknik dasar disamping harus memiliki kondisi fisik yang baik. Hal ini dikarenakan penguasaan teknik dasar bermain bola voli merupakan modal utama untuk bermain bola voli, dalam permainan bola voli teknik dasar mutlak harus dikuasai oleh pemain. Teknik dasar bermain bola voli dibagi menjadi dua, yaitu teknik badan (teknik tanpa bola) meliputi: 
cara lari, cara melompat, gerak tanpa bola,bloking dan teknik dasar dengan bola meliputi: servis, pasing,dan smash.

Dalam permainan bola voli saat sekarang ini seorang pemain bola voli dituntut untuk dapat melakukan bloking yang benar. Meloncat yang keras, kuat, baik, tolakan, dan tepat pada sasaran akan lebih memudahkan untuk menjaga pertahanan dari serangan lawan. Daya ledak yaitu perpaduan kekuatan dan kecepatan (Johansyah, 2013). Untuk mendapatkan tolakan yang kuat dan kecepatan yang tinggi seorang atlet harus memiliki daya ledak yang besar. Jadi daya ledak otot tungkai sebagai tenaga pendorong lompatan pada saat melakukan tolakan pada papan tolak setelah melakukan awalan untuk memperoleh kecepatan vertical sehingga dapat menambah jarak lompatan yang dilakukan. Berdasarkan pada pengertian tentang power secara umum tersebut, maka dapat disimpulkan bahwa power tungkai adalah kemampuan otot tungkai untuk melakukan kerja atau gerakan secara eksplosif. Power tungkai merupakan kemampuan otot atau sekelompok otot tungkai untuk mengatasi tahanan beban atau dengan kecepatan tinggi dalam satu gerakan yang utuh. Power tungkai merupakan kemampuan untuk mengatasi tahanan beban atau dengan kecepatan tinggi (eksplosif) dalam satu gerakan yang utuh yang melibatkan otot-otot tungkai sebagai penggerak utama. Pelatihan kondisi fisik akan memberikan manfaat yang baik apabila diberikan pada masa adolesensi, karena masa adolensensi merupakan masa yang paling tepat dalam pencapaian kemampuan fisik yang optimal karena pada masa ini fungsi fisiologis tubuh mengalami perkembangan dengan kisaran umur 10 sampai 18 tahun untuk perempuan dan 12 sampai 20 untuk laki-laki (Sugiyanto, 1998: 8). Masa adolesensi adalah suatu fase perkembangan yang dinamis dalam kehidupan seorang individu. Masa ini merupakan periode transisi dari masa anak ke masa dewasa yang ditandai dengan percepatan perkembangan fisik, mental, emosional dan sosial dan berlangsung pada masa kehidupan (Fauzia, 2013). Jadi seperti yang diuraikan di atas, untuk mencapai kondisi fisik yang baik di bidang olahraga dapat diberikan pada masa adolesensi atau saat anak tersebut duduk di tingkat Sekolah Menengah Pertama (SMP), karena kemampuan fisiknya sedang mengalami proses pertumbuhan dan perkembangan.

Dari hasil observasi peneliti secara langsung di SMP Negeri Kabupaten Jembrana pada peserta putri bola voli, pembinaan komponen kondisi fisik dan keterampilan teknik dasar masih kurang diberikan, sehingga secara tidak langsung akan berdampak terhadap pencapaian prestasi olaraga di SMP Negeri Kabupaten Jembrana. Prestasi cabang olahraga bola voli di SMP Kabupaten Jembrana belum dapat menunjukkan prestasi yang maksimal, sesuai target yang ingin dicapai oleh sekolah. Penurunan Prestasi bola voli di Kabupaten Jembrana disebabkan oleh beberapa faktor seperti kurangnya pembinaan yang mengarah kepada kondisi fisik dan keterampilan teknik dalam permainan bola voli. Seperti yang diketahui pencapaian prestasi yang optimal akan dapat dicapai dengan penguasaan teknik permainan yang maksimal dan tingkat kondisi fisik yang baik dapat dimiliki dengan dilakukannya pelatihan yang mengarah pada penguasaan teknik permainan bola voli khususnya daya ledak otot tungkai. Pelatihan teknik yang diberikan masih menoton yang mengakibatkan kejenuhan pada siswa. Hal tersebut secara tidak langsung berdampak pada penurunan prestasi olahraga khususnya bola voli di SMP Negeri Kabupaten Jembrana. Pelatihan kondisi fisik seperti daya ledak otot tungkai harus mendapat perhatian dalam pembinaan prestasi bola voli.

Terkait dengan hal di atas, maka akan diberikan metode latihan yaitu metode latihan plyometrics untuk membentuk komponen kondisi fisik terutama daya ledak otot tungkai. Plyometrics berasal dari bahasa Yunani "plio" dan "metric" yang masing-masing berarti "lebih banyak" dan "ukuran". Plyometrics mengacu pada latihan-latihan yang ditandai dengan kontraksi otot yang kuat sebagai respon terhadap pembebanan yang cepat dan dinamis atau peregangan otot yang terlibat (Furqon \& Doewes, 2002: 2). 
Istilah plyometrics biasanya diterapkan untuk semua tipe pelatihan yang menghasilkan tegangan awal dan reflek regangan pada otot (Suratmin \& Adi, 2016). Plyometrics adalah latihan-latihan atau ulangan yang bertujuan menghubungkan gerakan kecepatan dan kekuatan untuk menghasilkan gerakan-gerakan eksplosif (Mahardika, 2020). Ada beberapa penelitian ilmiah yang telah dilakukan khususnya yang terkait dengan program latihan plyometrics, seperti hasil penelitian yang dilakukan oleh Setiawan (2016) di kota Kediri yang menemukan bahwa terdapat pengaruh daya ledak otot tungkai, kekuatan otot lengan, dan kelentukan otot punggung terhadap kemampuan smash dalam permainan bola voli pada atlet voli SMA Wahidiyah Kota Kediri. Senada dengan itu Puspita (2020) melakukan kajian literatur mengenai latihan pliometrik dari 19 artikel hasil penelitian, hasilnya adalah latihan pliometrik terbukti efektif dalam meningkatkan power otot lengan dan power otot tungkai, latihan pliometrik dapat dilakukan secara individu atau dengan bantuan teman, dan untuk hasil yang lebih baik latihan pliometrik dapat dilakukan dengan menambahkan beban.

Pengamatan dan pengalaman peneliti metode latihan plyometrics belum pernah diterapkan oleh pelatih pada pemain bola voli putri SMP Kabupaten Jembrana. Latihan yang diberikan biasanya hanya jogging, langsung latihan gerakan pasing ,smash , dan melakukan game internal.Keunggulan dari pelatihan quick leap dan doubele leg speed hop dibandingkan dengan pelatihan yang lain, yaitu (1) dilihat dari gerakannya tidak terlalu sulit dilakukan, (2) pelatihan ini tidak memerlukan tempat yang terlalu luas, dan (3) gerakan yang dilakukan menekankan pada daya ledak otot tungkai. Betitik tolak dari uraian di atas, peneliti terdorong melakukan penelitian dengan judul "pengaruh pelatihan pliometrik kecepatan terhadap daya ledak otot tungkai pemain bola voli putri SMP Kabupaten Jembrana

\section{METODE}

Penelitian ini menggunakan metode penelitian kuantitatif yang termasuk di dalam penelitian eksperimen. Desain penelitian yang digunakan dalam penelitian ini adalah Treatment by level $2 \times 2$. Populasi pada penelitian ini adalah 75 peserta Bola Voli SMP Negeri Kabupaten Jembrana. Sampel berjumlah 40 orang dipilih berdasarkan katagori daya ledak otot tungkai tinggi dan rendah. Variabel bebas pada penelitian ini adalah metode latihan quck leap dan doubele leg speed hop, sedangkan variabel terikat pada penelitian ini adalah daya ledak otot tungkai. Teknik pengumpulan data pada penelitian ini akan menggunakan teknik instrument administration. Tempat pelatihan dilakukan di Lapangan SMPN 6 Negara dan waktu penelitian dilakukan selama 4 minggu dengan frekuensi 3 kali seminggu dan dilakukan pada pagi hari pukul 06.30 WITA.

Instrumen yang digunakan dalam penelitian ini adalah vertical jump untuk mengukur daya ledak (power) otot tungkai dengan melakukan percobaan melakukan 3 kali kesempatan (Widiastuti, 2011: 102). Teknik analisis data menggunakan uji anava dua jalur dan uji tukey dengan bantuan komputer program SPSS 16.0 pada taraf signifikansi (a) 0,05. 


\section{HASIL DAN PEMBAHASAN}

Hasil

Tabel 1. Rekapitulasi Hasil Penghitungan Gain Skor Daya Ledak Otot Tungkai

\begin{tabular}{|l|r|r|r|r|r|r|r|r|}
\hline $\begin{array}{l}\text { Data } \\
\text { Statistik }\end{array}$ & A1 & A2 & B1 & B2 & A1B1 & A1B2 & A2B1 & A2B2 \\
\hline Mean & 31.35 & 28.95 & 35.35 & 24.95 & 35.90 & 26.80 & 34.80 & 23.10 \\
\hline Median & 31.50 & 30.00 & 36.00 & 24.50 & 36.00 & 27.50 & 35.50 & 22.50 \\
\hline Std. Deviasi & 5.575 & 6.848 & 3.360 & 3.576 & 2.961 & 3.293 & 3.795 & 2.923 \\
\hline Varians & 31.08 & 46.89 & 11.29 & 12.79 & 8.77 & 10.84 & 14.40 & 8.54 \\
\hline $\begin{array}{l}\text { Skor } \\
\text { Minimum }\end{array}$ & 20 & 21 & 10 & 13 & 9 & 12 & 10 & 11 \\
\hline $\begin{array}{l}\text { Skor } \\
\text { Maksimum }\end{array}$ & 20 & 19 & 30 & 19 & 31 & 20 & 30 & 19 \\
\hline Rentangan & 40 & 40 & 40 & 32 & 40 & 32 & 40 & 30 \\
\hline Jumlah & 627 & 579 & 707 & 499 & 359 & 268 & 348 & 231 \\
\hline
\end{tabular}

Sesuai dengan table 1 dapat dilihat bahwa nilai rata-rata daya ledak otot tungkai yang mengikuti pelatihan PQL adalah 31.35 dengan standar deviasi 5.58 sedangkan nilai rata-rata daya ledak otot tungkai yang mengikuti PDLSH adalah 28.95 dengan standar deviasi 6.85. Nilai rata-rata daya ledak otot tungkai (DLOT) pada semua kecepatan $(n=20)$ dalam kelompok PQL sebesar 31.35 dengan standar deviasi 5.58. Sedangkan, dalam kelompok yang mengikuti PDLSH nilai rata-rata daya ledak otot tungkainya sebesar 28.95 dengan standar deviasi 6.85. Tampak bahwa secara deskriptif hasil ini menunjukkan bahwa PQL lebih baik sebagai fasilitas belajar bagi siswa dalam rangka mencapai daya ledak otot tungkai dalam permainan voli.

Jika dilihat dari perbandingan antar jenis kecepatan. tampak bahwa kelompok siswa yang memiliki kecepatan tinggi menunjukkan daya ledak otot tungkainya dengan skor rata-rata $=35,35$ dengan $S D=3,36$ dan kelompok siswa yang memiliki jenis kecepatan rendah memiliki skor rata-rata $=24,95$ dengan $S D=3,58$. Hasil ini mengindikasikan bahwa secara deskriptif kelompok siswa yang memiliki kecepatan tinggi menunjukkan daya ledak otot tungkainya lebih baik dibandingkan dengan kelompok siswa yang memiliki kecepatan rendah.

\section{Pembahasan}

Secara teoritis hasil pelatihan quick leap berpengaruh terhadap peningkatan power otot tungkai dapat dijelaskan sebagai berikut: gerakan pada pelatihan quick leap bersifat tiba-tiba atau ekplosif ini tentunya akan sangat baik untuk perkembangan power otot tungkai yang hendak dilatih. Secara khusus gerakan ini mengembangkan otot-otot fleksors pinggul, quadriceps, gluteals, punggung bagian bawah, shoulder girdle. besar kecilnya daya ledak yang dihasilkan oleh otot tungkai sangat dipengaruhi oleh kontraksi otot itu sendiri. Mekanisme gerakan quick leap yaitu gerakan melompat yang dilakukan secara berulang-ulang dan memerlukan permukaan pendaratan yang agak lunak seperti rumput atau matras gulat dan bangku, tempat duduk tanpa sandaran atau kotak dengan ketinggian kira-kira 12-24 inci, akan memberikan suatu pembebanan terutama meningkatnya massa dan panjang otot tungkai yang dilatih. Dengan meningkatnya massa dan panjang otot tungkai secara tidak langsung akan 
ISSN 2356-3397 (Print) | ISSN 2597-4505 (Online)

mempengaruhi power otot tungkai. Pelatihan ini menerapkan beberapa prinsip pelatihan seperti: prinsip overload dengan pemberian beban secara progresif yaitu penambahan jumlah set dan repetisi di setiap minggu pelatihan. Semakin banyak beban yang diberikan menyebabkan otot membesar. Pembesaran otot ini terjadi karena membesarnya diameter pada serabut otot. Prinsip reversibility untuk mengantisipasi situasi dan kondisi lapangan yang terbuka, sehingga saat hujan siswa tetap diberikan pelatihan yang dilaksanakan di ruangan tertutup hal ini menyebabkan otot tungkai tetap diberikan beban secara terstuktur, prinsip spesifikasi diterapkan khusus untuk melatih otot tungkai yang otot antagonisnya juga terlatih. Hasil penelitian ini sejalan dengan temuan Darmadi et al (2017) yaitu pelatihan quick leap berpengaruh terhadap peningkatan daya ledak otot tungkai dengan mean difference 28,47 dimana pelatihan ini memberikan pengaruh yang lebih baik dibandingkan dengan side jump sprint terhadap daya ledak.

Berdasarkan hasil analisis deskriptif dan uji anava 2 Jalur, secara keseluruhan dapat dinyatakan bahwa terdapat perbedaan hasil pada peserta yang mendapatkan latihan quick leap dan latihan doubele leg speed hop. Hasil vertical jump pada peserta yang mendapatkan latihan quick leap lebih baik dari latihan doubele leg speed hop. Hal tersebut dikarenakan, latihan quick leap lebih mudah dengan menggunakan box dan melakukan tolakan ke atas setinggi-tngginya dengan tolakan yang keras sedangkan untuk latihan doubele leg speed hop dilakukan dengan melompat ke depan tanda menggunakan alat san sangat sulit untuk bergerak ke atas sehingga gerakannya lebih sulit. Metode latihan yang diberikan mengakibatkan kondisi anatomi dan fisiologis dari otot tungkai. Pembebanan yang diberikan terhadap otot tungkai melalui pelatihan quick leap dan doubele leg speed hop akan menyebabkan perubahan peningkatan daya ledak otot tungkai. Latihan quick leap merupakan gerakan dari plyometrics yang dirancang untuk mengerakkan, otot-otot fleksors pinggul, quadriceps, gluteals, punggung bagian bawah, shoulder girdle Plyometric mengacu pada latihan-latihan yang ditandai dengan kontraksi-kontraksi otot yang kuat sebagai respon terhadap pembebanan yang cepat dan dinamis atau peregangan otot yang terlibat. Latihan plyometrics diperkirakan dapat menstimulus berbagai perubahan sistem neuromuskular, memperbesar kemampuan kelompok-kelompok otot untuk memberikan respon lebih cepat dan lebih kuat terhadap perubahan-perubahan yang ringan dan cepat.

Pelatihan Plyometrics merupakan salah satu usaha yang ditujukan untuk mengembangkan daya ledak eksplosif dan kecepatan reaksi (Nala, 2011) Istilah ini sering digunakan dalam menghubungkan gerakan lompat yang berulang-ulang untuk menghasilkan reaksi yang eksplosif. Prinsip metode pelatihan plyometrics adalah otot selalu berkontraksi baik memanjang (eccentric) maupun saat memendek (concentric). Latihan plyometrics diperkirakan dapat menstimulus berbagai perubahan sistem neuromuskular, memperbesar kemampuan kelompok-kelompok otot untuk memberikan respon lebih cepat dan lebih kuat terhadap perubahan-perubahan yang ringan dan cepat. Latihan quick leap dan doubele leg speed hop ini merupakan suatu pelatihan yang menggunakan sistem energi predominan anaerob dengan adanya pembebanan tersebut, akan mengakibatkan terjadinya hipertrofi otot. Efek yang ditimbulkan dari hipertrofi otot itu akan mengakibatkan terjadinya peningkatan kekuatan otot tungkai. Pertambahan massa otot disebabkan oleh bertambahnya myofibril/ serabut halus otot sehingga sel otot bertambah besar dan terjadi hipertrofi (Setijono, 2001: 23).

Hasil penelitian berikutnya adalah terdapat pengaruh interaksi antara model pelatihan Pleometrik dan kecepatan terhadap daya ledak otot tungkai. Berdasarkan pengujian hipotesis yang kelima dalam pencapaian daya ledak otot tungkai, model pelatihan Pleometrik dan kecepatan berinteraksi secara signifikan $(p<0,05)$. Profil pola interaksi antara kedua variabel independen tersebut tampaknya penting untuk ditampilkan. Tampilan tersebut akan memberikan gambaran visual salah satu di antara 


\section{Volume 8, Nomor 1, April 2021 \\ ISSN 2356-3397 (Print) | ISSN 2597-4505 (Online)}

PQL dan PDLSH yang paling akomodatif sebagai model pelatihan Pleometrik yang diterapkan pada pemain voli yang memiliki kecepatan tinggi atau kecepatan rendah dalam pencapaian daya ledak otot tungkai. Seperti Penelitian oleh (Sugihartono \& Arwin, 2019) tentang pengaruh antara latihan pliometrik double leg speed hop dan single leg speed hop terhadap kemampuan lompat jauh gaya jongkok. Karena latihan pliometrik double leg speed hop dan single leg speed hop memiliki kelebihan dan kelemahan yang berbeda. Latihan pliometrik double leg speed hop mengembangkan kekuatan otot tungkai dan keseimbangan saat melayang di udara. Latihan pliometrik single leg speed hop mengembangkan kekuatan otot tungkai dan teknik lepas landas.

Selanjutnya, hasil penelitian juga menunjukkan terdapat perbedaan pengaruh yang signifikan antara metode latihan quick leap dan doubele leg speed hop pada peserta yang memiliki daya ledak otot tungkai kecepatan tinggi. Pengujian hipotesis ini menunjukkan bahwa metode latihan dquick leap pada peserta yang memiliki daya ledak otot lengan tinggi memberikan peran stategis dan memiliki kemampuan yang baik, sehingga saat diberikan pelatihan peserta dapat melakukan gerakan dengan baik. hal ini didukungn dengan gerakan latihan quick leap lebih sesuai dengan gerakan vertical jump yaitu lemparan ke depan sedangkan latihan doubele leg speed hop dilakukan dengan gerakan lemparan ke depan tanpa menggunakan alat bantu. Keuntungan bagi para pemain yang memiliki daya ledak otot tungkai kecepatan tinggi adalah 1) memudahkan dalam menampilkan berbagai kemampuan gerak dan keterampilan daya ledak otot tungkai. 2) menghindarkan diri dari kemungkinan mendapatkan cedera pada saat melakukan gerakan vertical jump. 3) memperlancar aliran darah sehingga sampai pada serabut otot. Peserta yang memiliki daya ledak otot tungkai tinggi mempengaruhi hasil vertical jump. Gerakan yang lues akan menghasilkan gerakan yang hemat energi sehingga dengan perbedaan metode latihan quick leap dan doubele leg speed hop yang memiliki daya ledak otot tungkai kecepatan tinggi akan memberikan perbedaan pengaruh terhadap power dalam permainan bola voli.

Pengujian hipotesis ini menunjukkan bahwa metode latihan quick leap pada peserta yang memiliki daya ledak otot tungkai kecepatan rendah memberikan peran stategis dan memiliki kemampuan yang baik, sehingga saat diberikan pelatihan peserta dapat melakukan gerakan dengan baik. hal ini didukungn dengan gerakan latihan quick leap lebih sesuai dengan gerakan lemparan ke depan sedangkan latihan medicine ball scoop toss dilakukan dengan gerakan lemparan ke depan tanpa menggunakan alat. Melakukan gerakan metode latihan tentu membutuhkan daya ledak otot tungkai dalam gerakan untuk mendapatkan hasil yang optimal. Daya ledak kemampuan untuk melakukan aktivitas secara tiba-tiba dan cepat dengan mengerahkan seluruh kekuatan dalam waktu yang singkat. Pada metode latihan quick leap dan doubele leg speed hop dibutuhkan daya ledak otot tungkai yang maksimal agar mendapatkan hasil yang optimal. Latihan plyometrics dapat menstimulus berbagai perubahan sistem neuromuskular, memperbesar kemampuan kelompok-kelompok otot untuk memberikan respon lebih cepat dan lebih kuat terhadap perubahan-perubahan yang ringan dan cepat. Peserta yang diberikan metode latihan quick leap dan doubele leg speed hop yang memiliki daya ledak otot tungkai kecepatan rendah memberikan perbedaan pengaruh terhadap daya ledak otot tungkai pada peserta bola voli. Dengan diberikannya metode pelatihan maka akan memberikan peningkatan terhadap kekuatan dan kecepatan otot tungkai, dan secara langsung akan memberikan dampak terhadap daya ledak otot tungkai 
ISSN 2356-3397 (Print) | ISSN 2597-4505 (Online)

\section{SIMPULAN DAN SARAN \\ Simpulan}

Berdasarkan hasil analisis dan pembahasan maka simpulan yang dapat ditarik pada penelitian ini adalah sebagai berikut.

1) Pelatihan pliometrik (quick leap dan doubele leg speed hop) berpengaruh signifikan terhadap daya ledak otot tungkai.

2) Terdapat interaksi antara bentuk pelatihan dan kecepatan terhadap daya ledak otot tungkai.

3) Power otot tungkai yang mendapatkan pelatihan (quick leap) lebih baik dari pelatihan pliometrik (doubele leg speed hop) pada peserta yang memiliki daya ledak otot tungkai kecepatan tinggi.

4) Power otot tungksi yang mendapatkan pelatihan (quick leap) lebih baik dari pelatihan pliometrik (doubele leg speed hop) pada peserta yang memiliki daya ledak otot tungkai kecepatan rendah.

\section{Saran}

Berdasarkan hasil penelitian di atas, hal-hal yang dapat disarankan adalah sebagai berikut, yaitu:

1) Untuk meningkatkan kemampuan kondisi fisik dapat melakukan pelatihan (quick leap dan doubele leg)

2) Pembina olahraga, pelatih olahraga, PJOK dan atlet serta pelaku olahraga lainnya dapat menggunakan pelatihan (quick leap dan doubele leg speed hop) yang terprogram dengan baik dan dalam menyusun program pelatihan diharapkan untuk dapat menyusun program pelatihan yang berbeda sesuai kebutuhan dan kemampuan dari atlet tersebut agar nantinya dapat memberikan hasil yang maksimal dalam meningkatkan kondisi fisik terutama daya ledak otot tungkai.

3) Bagi pembina ekstrakurikuler jangan mengesampingkan variabel kondisi fisik daya ledak dalam setiap melatih kondisi fisik lainnya karena daya ledak merupakan penunjang kondisi fisik yang lain.

4) Bagi pelatih/pembina olahraga untuk meningkatkan kemampuan keterampilan tidah cukup hanya dengan melakukan pelatihan fisik saja tetapi harus melatih keterampilan gerak yang ingin ditingkatkan.

5) Peneliti lain bahwa dengan menggunakan pelatihan pliometrik (quick leap dan doubele leg speed hop), yang nantinya akan memberikan pengaruh terhadap daya ledak otot tungkai pada cabang olahraga bolavoli.

6) Bagi peneliti lain yang ingin melakukan penelitian sejenis untuk menggunakan variabel dan sampel penelitian yang berbeda dengan memperhatikan kelemahankelemahan yang ada pada penelitian ini sebagai bahan perbandingan.

\section{DAFTAR PUSTAKA}

Ariani, L. P. T. (2011). Dasar-Dasar Kepelatihan Olahraga. Universitas Pendidikan Ganesha.

Darmadi, I. K., Sudiana, I. K., Tisna, G. D., \& Or, S. (2017). Pengaruh Pelatihan Quick Leap Dan Side Jump Sprint Terhadap Peningkatan Daya Ledak Otot Tungkai. Jurnal IImu Keolahragaan Undiksha, 5(1), 12-23.

Fauzia, Y. (2013). Hubungan Indeks masa tubuh dan usia dengan Kadar asam urat pada remaja pra-Obese dan Obese Di purwokerto. Purwokerto: Universitas Jendral Soedirman.

Furqon, H., \& Doewes, M. (2002). Pliometrik Untuk Meningkatkan Power. Program Pasca Sarjana Universitas Sebelas Maret.

Johansyah. (2013). Penyusunan Program Latihan. Raja Grafindo. 
Mahardika, I. W. (2020). Pengaruh Metode Latihan Dan Daya Ledak Otot Lengan Terhadap Throw In Sepakbola. PENDASI: Jurnal Pendidikan Dasar Indonesia, 4(2), $1-11$.

Nala, I. G. N. (2011). Prinsip Pelatihan Fisik Olahraga. Universitas Udayana.

Puspita, P. A. (2020). Efektifitas Latihan Pliometrik Dalam Meningkatkan Power. Seminar \& Conference Nasional Keolahragaan, 1.

Setiawan, B. (2016). Pengaruh Daya Ledak Otot Tungkai, Kekuatan Otot Lengan, Dan Kelentukan Otot Punggung Terhadap Kemampuan Smash Dalam Permainan Bola Voli Pada Atlet Voli SMA WAHIDIYAH KOTA KEDIRI TESIS. UNIVERSITAS NUSANTARA PGRI KEDIRI.

Setijono, dkk. (2001). Instruktur Fitness. Unesa University Press.

Sugihartono, T., \& Arwin, A. (2019). Perbedaan Pengaruh Latihan Pliometrik Single Leg Speed Hop Dan Double Leg Speed Hop Terhadap Kemampuan Lompat Jauh Gaya Jongkok DI SMA NEGERI 08 BENGKULU UTARA. Kinestetik: Jurnal IImiah Pendidikan Jasmani, 3(1), 87-94.

Sugiyanto. (1998). Perkembangan dan Belajar Motorik. Universitas Terbuka.

Sukradati, P., Marhaeni, M. A. P. A. A. I. N., \& Sutama, M. P. P. I. M. (2013). Studi Evaluasi Pelaksanaan Program Pengembangan Diri Pada Sd Negeri Di Kecamatan Sukasada. Ganesha University of Education.

Suratmin, S., \& Adi, I. P. P. (2016). Penerapan Metode Pelatihan Pliometrik Dalam Meningkatkan Power Otot Tungkai Atlet Pplm Bali. Journal of Physical Education Health and Sport, 3(1), 33-43.

Widiastuti. (2011). Tes dan Pengukuran Olahraga. PT Bumi Timur. 